\title{
EVALUASI ASPEK FARMASETIK DAN AKTIVITAS ANTIBAKTERI SECARA IN-VITRO KIT DIAGNOSTIK 99MTC-KANAMYCIN
}

\section{EVALUATION OF PHARMACEUTICAL ASPECTS AND IN-VITRO ANTIBACTERIAL ACTIVITY OF 99MTC-KANAMYCIN DIAGNOSTIC KITS}

\author{
Eva Maria Widyasari, Maula Eka Sriyani, lim Halimah, Hendris Wongso, Teguh Hafiz Ambar Wibawa, \\ Iswahyudi, Ahmad Sidik \\ Pusat Sains dan Teknologi Nuklir Terapan - Badan Tenaga Nuklir Nasional \\ Jl. Tamansari No. 71 Bandung
}

Diterima 8 Juli 2014, diterima dalam bentuk perbaikan 16 Oktober 2014, disetujui 6 Nopember 2014

\begin{abstract}
ABSTRAK
EVALUASI ASPEK FARMASETIK DAN AKTIVITAS ANTIBAKTERI SECARA IN-VITRO KIT DIAGNOSTIK 99mTc-KANAMYCIN. Angka kematian akibat infeksi dari tahun ke tahun terus meningkat. Berbagai usaha terus dilakukan guna menekan angka kematian yang ada, salah satu contohnya dengan pengembangan metode diagnostik berbasis nuklir. ${ }^{99 m}$ Tc-Kanamycin merupakan kit diagnostik potensial untuk dikembangkan menjadi senyawa bertanda yang dapat digunakan dalam mendiagnosis penyakit infeksi. Kanamycin adalah sebuah antibiotik berspektrum kerja luas yang telah lama digunakan dalam menekan pertumbuhan bakteri baik itu bakteri Gram positif maupun Gram negatif. Selain harus memenuhi standar sifat fisika dan kimia, ${ }^{99 m} T c-$ Kanamycin juga harus melalui tahapan uji preklinis sebelum diuji cobakan pada manusia (uji klinis). Berbagai aspek farmasetik yang dilakukan dalam penelitian ini meliputi uji sterilitas, uji pirogenitas dan uji toksisitas, serta uji aktivitas antibakteri. Dari penelitian ini didapatkan hasil bahwa sediaan ${ }^{99 m}$ Tc-Kanamycin steril, bebas pirogen, tidak toksik dan daya hambat terhadap bakteri relatif sama dengan Kanamycin tidak bertanda radioaktif. Uji uptake sediaan terhadap bakteri optimum pada waktu 24 jam inkubasi pada suhu $37 \circ \mathrm{C}$. Hasil uji uptake maupun uji daya hambat terhadap bakteri menunjukkan bahwa ${ }^{99 m}$ Tc-Kanamycin lebih aktif terhadap bakteri S.aureus dibandingkan terhadap E.coli.
\end{abstract}

Kata kunci: preklinis, kanamycin, diagnostic, infeksi

ABSTRACT

EVALUATION OF PHARMACEUTICAL ASPECTS AND IN-VITRO ANTIBACTERIAL ACTIVITY OF 99mTCKANAMYCIN DIAGNOSTIC KITS. The mortality rate due to infection has been increased every year. Various efforts have been conducted in order to reduce the number of mortality by bacterial infection, such as the development of nuclear-based diagnostic methods. ${ }^{99 \mathrm{~m}} \mathrm{Tc}$-Kanamycin is one of the potential diagnostic kits to be developed as a labelled compound for diagnosing of bacterial infection. Kanamycin is a wide broadspectrum antibiotic agent to inhibit the growth of Gram positive or negative bacteria. Besides it must comply to the chemical and physical standard properties, the ${ }^{99 m T c-K a n a m y c i n ~ m u s t ~ g o ~ t h r o u g h ~ t h e ~ p r e c l i n i c a l ~ t e s t ~}$ before the clinical trial phase. The pharmaceuticals aspects test performed in this study covering sterility, pirogenity and toxicity test, as well as antibacterial activity test. The result was shown that ${ }^{99 \mathrm{~m} T c-K a n a m y c i n}$ was sterile, pirogen free, non toxic and the bacterial inhibition of ${ }^{99 m} \mathrm{mc}$-Kanamycin relatively similar with unlabelled Kanamycin. The optimum uptake of $99 \mathrm{~m} T \mathrm{c}$-Kanamycin to the bacteria was obtined after 24 hours of incubation at $37{ }^{\circ} \mathrm{C}$. Both uptake and inhibition test showed that ${ }^{99 m} \mathrm{Tc}-$ kanamycin was more active against S. aureus bacteria compared to E.coli.

Keywords: preclinical study, kanamycin, diagnostic, infection

\section{PENDAHULUAN}

Infeksi merupakan penyakit yang penyebarannya sangat luas dan dapat menjangkiti seluruh lapisan masyarakat. Tingginya angka kematian akibat infeksi ini menggugah para peneliti di BATAN untuk berperan aktif membantu mengatasi masalah infeksi dengan menggunakan teknik nuklir. Infeksi adalah keadaan masuknya mikroorganisme 
patogen ke dalam tubuh makhluk hidup, kemudian berkembangbiak dan menyebabkan terjadinya kerusakan jaringan yang ditandai dengan timbulnya berbagai macam gejala penyakit. Infeksi sebagian besar diikuti dengan peradangan atau inflamasi, yang didefinisikan sebagai reaksi mikrosirkulasi yang ditandai dengan perpindahan cairan dan sel darah putih dari darah ke dalam jaringan ekstraselular (1). Sejak awal tahun 2000 para peneliti di BATAN telah mengembangkan kit diagnostik untuk infeksi dengan menggunakan senyawa-senyawa antibiotik yang dalam perkembangannya diketahui lebih efektif untuk membedakan antara inflamasi yang disebabkan karena infeksi (infective inflamatory) atau yang bukan disebabkan oleh infeksi (non-infective inflammatory). Kit diagnostik untuk infeksi dengan menggunakan senyawa antibiotik yang telah berhasil diteliti dan dikembangkan tersebut di antaranya adalah kit diagnostik 99mTc-siprofloksasin dan 99mTc-etambutol (2,3). Kedua kit tersebut telah melalui uji klinis dan direkomendasikan oleh dokter-dokter di komunitas kedokteran nuklir sebagai kit untuk diagnosis infeksi. Namun demikian, mengingat beragamnya jenis infeksi disertai dengan mekanisme kerja yang berbeda, masih diperlukan sediaan-sediaan diagnostik yang lebih selektif berbasis antibiotik bertanda radioaktif.

Kanamycin merupakan antibiotik yang termasuk dalam golongan aminoglikosida yang bekerja menghambat proses sintesis protein mikroorganisme. Sifatnya sebagai antibiotika berspektrum luas memungkinkannya dapat berikatan dengan bakteri Gram negatif maupun Gram positif. Kanamycin digunakan untuk pengobatan infeksi, jika penisilin ataupun obat yang kurang toksik lainnya tidak dapat digunakan $(4,5,6)$. Adapun infeksi yang biasanya diobati menggunakan Kanamycin adalah infeksi pada tulang saluran pernafasan, kulit, jaringan lunak, perut, dan infeksi pada saluran kemih (4). Pada penelitian sebelumnya telah berhasil dilakukan penandaan Kanamycin dengan radionuklida 99mTc-Kanamycin dengan efisiensi penandaan di atas $95 \%$ (7) dan telah dilakukan penentuan karakteristik fisikokimia kit kering Kanamycin untuk menjamin aplikasinya nanti ketika digunakan untuk pasien (8).

Radiofarmaka merupakan sediaan steril yang siap diberikan kepada pasien. Oleh karena itu perlu dilakukan pemeriksaan aspek farmasetiknya untuk mengetahui kelayakannya untuk diberikan kepada pasien. Aspek farmasetik yang pertama ditentukan adalah sterilitas, hal ini dilakukan untuk mengetahui apakah ada kontaminan baik berupa jamur atau bakteri pada sediaan kit kering Kanamycin yang telah dibuat. Aspek farmasetik yang kedua adalah pirogenitas yaitu pengujian untuk mengetahui apakah sediaan ${ }^{99 m} \mathrm{Tc}$-Kanamycin bebas pirogen. Aspek farmasetik yang ketiga adalah toksisitas yaitu pengujian yang bertujuan untuk mengetahui apakah sediaan 99mTc-Kanamycin yang telah dibuat memiliki efek toksik/berbahaya. Selain ketiga aspek farma setik tersebut juga dilakukan uji daya hambat terhadap bakteri untuk mengetahui apakah ada perubahan aktivitas antibakteri Kanamycin setelah bertanda radioaktif dan uji uptake terhadap bakteri yang bertujuan untuk mengetahui nilai uptake sediaan ${ }^{99 m T c-K a n a m y c i n ~ t e r h a d a p ~ b a k t e r i ~ S . ~ a u r e u s ~ d a n ~ E . c o l i . ~ D a r i ~ p e n e l i t i a n ~ i n i ~ d i h a r a p k a n ~ k i t ~ K a n a m y c i n ~}$ yang telah berhasil diformulasi dapat memenuhi standar yang telah ditetapkan farmakope, sehingga dengan terpenuhinya standar dalam pengujian preklinis maka kit diagnostik tersebut dapat memasuki tahap uji selanjutnya yaitu uji klinis.

\section{METODOLOGI}

\section{Bahan dan Alat}

\section{a. Bakteri}

Bakteri yang digunakan dalam penelitian ini adalah bakteri Staphylococcus aureus (wild-type) dan Escherichia coli (wild-type), diperoleh dari laboratorium Mikrobiologi ITB. Untuk mengembangbiakkannya, kedua jenis bakteri tersebut dikultur pada medium padat nutrient agar.

\section{b. Hewan}

Pada penelitian ini digunakan 2 jenis hewan yaitu mencit putih (Mus musculus) strain Swiss dan kelinci. Penggunaan kedua jenis hewan tersebut berdasarkan pada metode yang terdapat di dalam Farmakope Indonesia Edisi IV dan prosedur umum pengawasan kualitas radiofarmaka. Mencit digunakan untuk uji toksisitas, sementara kelinci untuk uji pirogenitas. Pemilihan kelinci untuk digunakan dalam uji pirogenitas dikarenakan sifatnya yang mampu mendeteksi semua jenis pirogen termasuk endotoksin ${ }^{(9,10)}$. Mencit putih yang digunakan berjenis kelamin 
jantan berumur $4-5$ minggu dengan berat badan antara $30-40 \mathrm{~g}$. Sedangkan hewan untuk uji pirogenitas adalah kelinci putih dengan umur $2-3$ bulan dan berat badan berkisar antara $2-3 \mathrm{~kg}{ }^{(9)}$.

\section{c. Bahan kimia}

Bahan utama yang digunakan dalam penelitian ini adalah kit kering Kanamycin, larutan radionuklida 99mTcperteknetat (PT. BATAN Teknologi), NaCl fisiologis (IPHA), aquabidest steril pro-injeksi (IPHA Laboratories, Indonesia), alkohol $70 \%$, dan minyak nabati. Medium-medium yang digunakan dalam penelitian ini antara lain medium nutrient agar (Oxoid, Inggris), saboroud agar (Merck, Jerman) dan tioglikolat cair (Merck, Jerman) untuk uji sterilitas. Sedangkan untuk uji daya hambat terhadap bakteri digunakan media muller hinton agar (Oxoid, Inggris).

\section{d. Peralatan}

Peralatan yang digunakan antara lain syringe ukuran $1 \mathrm{~mL}$ untuk menyuntikkan radiofarmaka 99mTcKanamycin, termokopel, rabbit restrainer, timbangan hewan, timbangan analitis (Mettler Toledo), laminar airflow (BBL Biological Cabinet), incubator (Memmert), Single Channel Analyzer (Ortec) dan Dose Calibrator (Victoreen) sebagai pencacah radioaktivitas, autoklaf (Hirayama), incubator (Memmert), vortex, tabung reaksi, rak tabung reaksi, pipet mikro (Eppendorf), pinset, jarum ose, kertas merang, dan kertas tissue.

\section{Tata Kerja}

\section{a. Uji sterilitas}

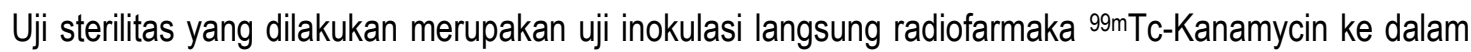
medium nutrient agar dan tioglikolat cair untuk pengujian bakteri dan saboroud agar untuk pengujian jamur (10). Pengujian dilakukan pada laminar airflow yang telah disterilkan dan dibersihkan. Kit kering Kanamycin disiapkan dengan menambahkan sebanyak $2 \mathrm{~mL} \mathrm{NaCl}$ fisiologis steril kedalam kit kering Kanamycin dan dikocok hingga homogen. Tutup kapas tabung perbenihan yang berisi medium tioglikolat cair dibuka di dekat api spiritus, kemudian kit kering Kanamycin diteteskan dengan syringe ke dalam medium tersebut kira-kira 0,2 ml, kemudian tabung ditutup kembali dengan kapas (triplo). Sebagai kontrol, satu tabung perbenihan berisi medium Tioglikolat cair dibiarkan terbuka dan diletakkan di dalam laminar airflow selama uji sterilitas dilakukan. Cawan petri berisi medium nutrient agar dibuka tutupnya di dekat lampu spiritus, kemudian kit kering Kanamycin dituangkan dipermukaan medium sebanyak $1 \mathrm{~mL}$, setelah itu tutupnya dipasang kembali (triplo). Sebagai kontrol, satu cawan petri berisi medium nutrient agar dibiarkan terbuka dan diletakkan di dalam laminar airflow selama uji sterilitas dilakukan. Cawan petri berisi saboroud agar dibuka tutupnya di dekat lampu spiritus, kemudian kit kering Kanamycin dituangkan dipermukaan medium sebanyak $1 \mathrm{~mL}$, setelah itu tutupnya dipasang kembali (triplo). Sebagai kontrol, satu cawan petri berisi medium saboroud agar dibiarkan terbuka dan diletakkan di dalam laminar airflow selama uji sterilitas dilakukan. Medium tioglikolat cair dan nutrien agar, baik yang berisi kit kering Kanamycin maupun kontrol diinkubasi di dalam inkubator dengan suhu $37^{\circ} \mathrm{C}$ selama 14 hari. Sedangkan medium saboroud agar baik yang berisi kit kering Kanamycin maupun kontrol diinkubasi di dalam suhu ruang $25^{\circ} \mathrm{C}$ selama 14 hari. Pertumbuhan bakteri maupun jamur diamati setiap hari selama 14 hari, dengan cara mengamati apakah ada koloni bakteri ataupun jamur pada medium nutrient agar dan mengamati keruh atau tidaknya medium tioglikolat cair. Jika media hasil uji menjadi keruh, berarti terdapat kontaminasi jamur ataupun bakteri.

\section{b. Pengujian pirogenitas}

Uji pirogenitas yang dilakukan merupakan Rabbit Pyrogen Test, dengan prosedur uji seperti yag tertera di dalam Farmakope Indonesia IV dan prosedur umum pengawasan kualitas radiofarmaka ${ }^{(9,10)}$. Pengujian ini menggunakan 3 ekor kelinci yang mula-mula ditentukan suhu tubuh awalnya pada 30 menit sebelum penyuntikan radiofarmaka. Suhu masing-masing kelinci diukur dengan memasukkan probe dari alat termokopel yang telah diolesi minyak nabati, ke dalam anus kelinci dengan kedalaman $\pm 2 \mathrm{~cm}$ hingga diperoleh suhu konstan. Radiofarmaka 99mTc-Kanamycin diinjeksikan secara intravena melalui vena auricularis di telinga kelinci pada menit ke- 0 . Suhu tubuh kelinci diukur kembali pada menit ke- 60,120, dan 180 (interval 60 menit setelah penyuntikan). Suhu tertinggi yang diperoleh mulai dari menit ke- 60 setelah penyuntikan sampai menit ke-180 disebut suhu maksimum. 
Dilakukan perhitungan dengan menggunakan persamaan berikut:

$T$ insial $=T$ pada $30^{\prime}$

$T$ respon $=T$ maksimal $-T$ inisial

- Suhu inisial ( $T$ inisial): suhu pada 30 menit sebelum injeksi.

- Suhu maksimal ( $T$ maksimal ): suhu tertinggi pada pengukuran 3 jam setelah penyuntikan.

- Suhu respon ( $T$ respon): selisih antara $T$ maksimal dan $T$ inisial.

\section{c. Uji toksisitas}

Uji toksisitas terhadap sediaan ${ }^{99 \mathrm{mTC}-k a n a m y c i n ~ m e n g a c u ~ p r o s e d u r ~ y a n g ~ t e r c a n t u m ~ d a l a m ~ F a r m a k o p e ~}$ Indonesia yaitu dengan menyuntikan secara intravena kepada 5 ekor mencit masing-masing $0,3 \mathrm{~mL}(\approx 325 \mu \mathrm{Ci})$ sediaan uji dengan dosis radioaktivitas 25 kali dosis manusia. Sediaan uji dinyatakan memenuhi syarat jika pada akhir 48 jam setelah penyuntikan semua hewan hidup atau tidak lebih dari seekor hewan menunjukkan gejala reaksi yang tidak biasa. Bila satu atau lebih hewan mati atau bila lebih dari seekor hewan menunjukkan gejala toksisitas abnormal/toksisitas yang tidak diinginkan dari bahan uji maka percobaan harus diulangi menggunakan paling sedikit 10 ekor mencit. Jika hewan uji tidak menunjukkan gejala abnormalitas pada akhir 48 jam setelah penyuntikan maka observasi dilanjutkan hingga 7 hari, dan dilanjutkan hingga 14 hari sambil tetap diberi pakan dan minum biasa ${ }^{(9)}$.

\section{d. Uji daya hambat terhadap bakteri}

Menyiapkan suspensi bakteri S.aureus dan E.coli dalam NaCl fisiologis dengan kepekatan $0,6 \times 10^{9} \mathrm{cfu}$ atau standar McFarland no 2. Biakan bakteri dioleskan di atas plat nutrien agar dan dibiarkan sekitar 15 menit. Kemudian di atas biakan diletakkan kertas cakram sebanyak 4 buah, 2 kertas cakram ditetesi masing-masing dengan $2 \times 10 \mu \mathrm{L}$ sediaan ${ }^{99 m T c-K a n a m y c i n ~ d a n ~} 2$ kertas cakram yang lainnya ditetesi dengan masing-masing 2 $\times 10 \mu \mathrm{L}$ Kanamycin tak bertanda radioaktif sebagai kontrol. Setiap pengerjaan dilakukan sebanyak 3 kali dan diulang sebanyak tiga kali dengan sediaan yang berbeda. Biakan kemudian disimpan dalam inkubator $37{ }^{\circ} \mathrm{C}$ selama 24 jam. Ukuran zona bening yang terjadi pada biakan plat agar menunjukkan aktivitas biologis masingmasing cuplikan.

\section{e. Uji uptake terhadap bakteri}

Uji uptake dilakukan untuk mengetahui persen ikatan bakteri dengan sediaan. Adapun caranya dilakukan dengan memasukkan $2 \mathrm{~mL}$ larutan $\mathrm{NaCl}$ fisiologis yang masing-masing mengandung $0,6 \times 10^{9} \mathrm{cfu}$ sel bakteri $\mathrm{S}$. aureus dan E.Coli ke dalam tabung sentrifugal kemudian ditambahkan $100 \mu \mathrm{L}$ radiofarmaka 99mTc-Kanamycin. Suspensi diinkubasi pada suhu $37^{\circ} \mathrm{C}$ selama waktu tertentu (1, 3, 5 dan 24 jam) sambil dikocok, kemudian disentrifugasi. Endapan dan supernatan dipisahkan, selanjutnya endapan dicuci dengan $0,5 \mathrm{~mL} \mathrm{NaCl}$ fisiologis dan dicacah. Sebagai kontrol digunakan larutan $\mathrm{Na}^{99 m} \mathrm{TcO}_{4}$ yang diperlakukan sama. Persen ikatan pada bakteri diperoleh dengan persamaan 3 :

$$
\% \text { ikatan pada bakteri }=\frac{\text { Cacahan endapan }}{\text { Cacahan }(\text { endapan }+ \text { supernatan })} \times 100 \%
$$

\section{HASIL DAN PEMBAHASAN}

Uji sterilitas untuk mengetahui apakah sedian yang telah dibuat steril atau bebas dari mikroba. Dari percobaan dengan pengulangan tiga kali didapatkan hasil bahwa sediaan Kanamycin dinyatakan steril karena setelah dilakukan pengamatan selama 14 hari tidak ditemukan pertumbuhan jamur maupun bakteri pada media nutrient agar, saboroud agar dan tioglikolat cair yang telah ditetesi larutan kit kering Kanamycin maupun pada media yang dibiarkan terbuka di dalam laminar airflow (LAF) selama pelaksanaan uji sterilitas. Jamur maupun bakteri tidak dijumpai tumbuh pada media perbenihan disebabkan radiofarmaka yang dibuat telah dibebaskan dari kontaminan dengan cara penyaringan menggunakan millipore pada saat pembuatannya. Selain itu kondisi ruang pembuatan kit kering Kanamycin serta prinsip kerja yang aseptis turut mendukung diperolehnya kit yang steril. Berdasarkan hasil tersebut, kit cair Kanamycin yang dibuat dinyatakan steril dan layak digunakan sebagai kit diagnostik untuk pencitraan infeksi.

Uji pirogenitas dilakukan untuk mengetahui apakah sediaan Kanamycin yang telah dibuat bebas pirogen/apirogen. Pirogen merupakan substansi yang mampu menyebabkan demam dan sering mencemari 
sediaan farmasi. Sampai saat ini, substansi pirogenik yang diketahui paling aktif dan paling sering mencemari sediaan farmasi adalah endotoksin. Selain itu masih banyak substansi pirogenik lainnya seperti bakteri, fungi, DNA-RNA virus dan lain-lain. Endotoksin merupakan bagian dari dinding sel mikroorganisme terutama dari bakteri Gram negatif yang terdiri atas suatu senyawa kompleks lipopolisakarida yang pirogenik (10). Uji pirogenitas dilakukan menggunakan metode rabbit pyrogen test terhadap 3 ekor kelinci yang telah diadaptasikan dahulu beberapa hari dengan lingkungan barunya. Percobaan dimulai dengan mengukur berat badan kelinci, yang diusahakan ketiganya memiliki berat badan yang hampir sama. Setelah itu suhu tubuh kelinci diukur sebagai suhu tubuh awal sebelum perlakuan. Farmakope Indonesia mensyaratkan bahwa suhu tubuh kelinci yang digunakan tidak boleh lebih besar dari $39,8{ }^{\circ} \mathrm{C}$ dan selisih suhu tubuh antar kelinci tidak boleh lebih besar dari $1{ }^{\circ} \mathrm{C}{ }^{(9)}$. Pengukuran suhu tubuh kelinci ini dilakukan dengan menggunakan termokopel yaitu sensor suhu yang dimasukkan ke dalam anus. Setelah prasyarat awal terpenuhi maka kelinci diberi perlakuan yaitu dengan menginjeksikan sediaan ${ }^{99 \mathrm{mTC}-K a n a m y c i n ~ s e c a r a ~ i n t r a v e n a ~ m e l a l u i ~ t e l i n g a ~ k e l i n c i ~ d e n g a n ~ d o s i s ~ s e b e s a r ~} 1 \mathrm{mCi} / 500 \mu \mathrm{L}$ dan suhu tubuh kelinci diukur kembali setelah 60, 120 dan 180 menit setelah perlakuan. Hasil pengamatan terhadap berat badan dan suhu tubuh kelinci disajikan dalam Tabel 1. Technical report IAEA (10) menyatakan bahwa sediaan radiofarmaka dinyatakan bebas pirogen jika jumlah kenaikan suhu tubuh ketiga kelinci setelah perlakuan adalah tidak lebih besar dari $1,5^{\circ} \mathrm{C}$ dan tidak ada kelinci yang kenaikan suhunya lebih dari $0,6{ }^{\circ} \mathrm{C}$. Dari pengujian sediaan Kanamycin yang tersaji dalam Tabel 1 menunjukkan bahwa respon suhu tubuh pada ketiga ekor kelinci yang telah diberi perlakuan ${ }^{99 \mathrm{mTC}} \mathrm{C}$-Kanamycin tidak mengalami kenaikan lebih besar dari $0,6{ }^{\circ} \mathrm{C}$ dan total respon kenaikan suhu tubuh ketiga kelinci tersebut tidak lebih dari $1,5^{\circ} \mathrm{C}$. Hal ini menunjukkan bahwa sediaan ${ }^{99 m T c-K a n a m y c i n}$ memenuhi syarat untuk dinyatakan sebagai sediaan yang bebas pirogen/apirogen.

Tabel 1. Berat badan dan respon suhu tubuh kelinci pada pengujian pirogenitas.

\begin{tabular}{cccccc}
\hline \multirow{2}{*}{ Kelinci } & \multirow{2}{*}{$\begin{array}{c}\text { Suhu Tubuh } \\
\text { Awal }\end{array}$} & \multicolumn{3}{c}{ Suhu Tubuh Kelinci Setelah Perlakuan $\left({ }^{\circ} \mathrm{C}\right)$} \\
\cline { 3 - 6 } & & 39,1 & $\mathbf{1 2 0}$ menit & $\mathbf{1 8 0}$ menit & $\begin{array}{c}\text { Selisih } \\
\text { tertinggi }\end{array}$ \\
\hline Kelinci I, 2,7 Kg & 38,8 & 38,8 & 39,3 & 39,6 & 0,5 \\
Kelinci II, 2,7 Kg & 38,8 & 39 & 0,2 \\
Kelinci III, 2,1 Kg & 39,4 & 39,2 & 39,0 & 39,3 & 0 \\
\hline \multicolumn{5}{c}{ Total respon ketiga kelinci } \\
\hline
\end{tabular}

Uji toksisitas sediaan ${ }^{99 m}$ Tc-Kanamycin dilakukan menggunakan 5 ekor mencit putih (Mus musculus) strain

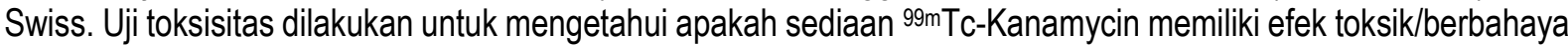
jika digunakan oleh makhluk hidup. Untuk memperoleh efek farmakologis yang setara dari sebuah radiofarmaka terhadap setiap spesies hewan percobaan diperlukan data mengenai penggunaan dosis secara kuantitatif. Hal ini sangat diperlukan jika obat tersebut akan digunakan untuk manusia, dan pendekatan terbaik adalah dengan menggunakan faktor konversi dosis yang diperoleh dari perhitungan perbandingan luas permukaan tubuh (Tabel 2).

Tabel 2. Faktor konversi dosis ${ }^{(11) .}$

\begin{tabular}{lccccc}
\hline & Mencit & Tikus & Kelinci & Kera & Manusia \\
\hline Mencit & 1,0 & 7,0 & 27,8 & 64,1 & 387,9 \\
Tikus & 0,14 & 1,0 & 3,3 & 9,2 & 56,0 \\
Kelinci & 0,04 & 0,25 & 1,0 & 2,4 & 14,2 \\
Kera & 0,016 & 0,11 & 0,42 & 1,0 & 6,1 \\
Manusia & 0,0026 & 0,018 & 0,07 & 0,16 & 1,0 \\
\hline
\end{tabular}

Dari Tabel 2 dapat diketahui bahwa faktor konversi dari manusia ke mencit adalah 0,0026. Dosis yang direncanakan akan digunakan untuk manusia normal adalah sebesar $5 \mathrm{mCi}$, dosis ini diperoleh dari diskusi langsung dengan dokter spesialis kedokteran nuklir yang sudah berpengalaman menggunakan berbagai 
radiofarmaka pada pasien. Guna menjamin keamanan pemakaian untuk manusia, dalam percobaan ini pengujian toksisitas radiofarmaka 99mTc-Kanamycin dilakukan menggunakan dosis yang lebih tinggi yaitu kurang lebih 25 kali dosis untuk manusia, sehingga dosis yang diinjeksikan ke mencit adalah $325 \mu \mathrm{Ci} \mathrm{mL}$. Pemilihan dosis yang ditinggikan hingga 25 kali ini untuk mengantisipasi jika penggunaan radiofarmka dilakukan beberapa kali pengulangan dimana dosis 25 kali masih akan lebih tinggi dibandingkan dosis yang telah diberikan dalam pengulangan tersebut.

Toksisitas suatu radiofarmaka dapat berasal dari radioaktivitas suatu radionuklida maupun dari molekul non radioaktif. Baik radiofarmaka yang digunakan untuk tujuan diagnosis maupun terapi, toksisitas dapat berasal dari kedua sumber tersebut, maupun dari hasil degradasi radiolisis ${ }^{(12)}$. Radiolisis adalah suatu peristiwa penguraian senyawa bertanda yang disebabkan oleh emisi radiasi yang dipancarkan oleh radionuklida di dalamnya. Semakin besar aktivitas spesifik suatu radionuklida, semakin besar pula efek radiolisisnya. Pada saat suatu ikatan kimia terputus oleh radiasi dari molekul itu sendiri, disebut dengan istilah autoradiolisis. Radiasi dapat menguraikan bahan pelarut, dan menghasilkan radikal bebas yang dapat memutuskan ikatan kimia dalam suatu senyawa bertanda (13). Komponen kimia non radioaktif yang terkandung dalam formulasi kit Kanamycin adalah Kanamycin (ligan), $\mathrm{SnCl}_{2} 2 \mathrm{H}_{2} \mathrm{O}$ (reduktor) dan Na-pirofosfat (ko-ligan). Material Safety Data Sheet melaporkan bahwa untuk mencit $L_{50}$ Kanamycin sulfat yang diberikan secara intravena adalah $225 \mathrm{mg} / \mathrm{kg}\left({ }^{(14)}, \mathrm{LD}_{50} \mathrm{SnCl}_{2} 2 . \mathrm{H}_{2} \mathrm{O}\right.$ adalah $250 \mathrm{mg} / \mathrm{kg}{ }^{(15)}$, dan $\mathrm{LD}_{50} \mathrm{Na}$-pirofosfat adalah $2980 \mathrm{mg} / \mathrm{kg}{ }^{(16)}$. Mengingat kadar Kanamycin, $\mathrm{SnCl}_{2} 2 . \mathrm{H}_{2} \mathrm{O}$ dan Napirofosfat yang terkandung dalam sediaan adalah berturut-turut $6 \mathrm{mg}, 300 \mu \mathrm{g}, 1,5 \mathrm{mg}$ maka jika sediaan ${ }^{99 \mathrm{~m} T \mathrm{c}-}$ Kanamycin bersifat toksik maka bukan berasal dari komponen kimia non radioaktif karena kadarnya sangat kecil. Oleh karena itu dalam penelitian ini yang diperhitungkan adalah dosis radioaktivitasnya. Dari Tabel 3 dapat diketahui bahwa uji toksisitas sediaan 99mTc-Kanamycin dengan dosis $325 \mu \mathrm{Ci}$ adalah tidak toksik atau aman karena tidak menunjukkan gejala abnormalitas seperti gelisah, kejang atau mati. Dari pengamatan setelah injeksi hingga 2 minggu paska injeksi semua mencit terpantau dalam kondisi baik dan tetap aktif seperti mencit lainnya yang tidak diberikan perlakuan.

Tabel 3. Hasil uji toksisitas dalam dosis $\pm 325 \mu \mathrm{Ci}$.

\begin{tabular}{cccccc}
\hline \multirow{2}{*}{ Mencit } & \multicolumn{5}{c}{ Pengamatan pada: } \\
\cline { 2 - 6 } & Setelah Injeksi & 24 jam & 48 jam & $\mathbf{1}$ minggu & $\mathbf{2}$ minggu \\
\hline 1 & Hewan normal & ya & ya & ya & ya \\
2 & Hewan normal & ya & ya & ya & ya \\
3 & Hewan normal & ya & ya & ya & ya \\
4 & Hewan normal & ya & ya & ya & ya \\
5 & Hewan normal & ya & ya & ya & ya \\
\hline
\end{tabular}

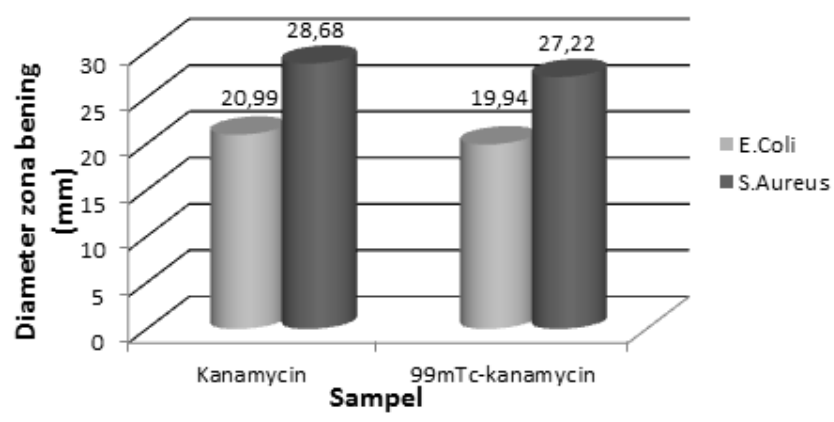

Gambar 1. Hasil pengujian daya hambat.

Pengujian selanjutnya adalah daya hambat 99mTc-Kanamycin terhadap bakteri. Pengujian ini dilakukan untuk mengetahui sensitivitas bakteri terhadap keberadaan senyawa yang berpotensi sebagai suatu bahan obat ${ }^{(17)}$. Hasil pengujian ditentukan di dalam media nutrien agar yang telah ditumbuhi bakteri dengan cara mengukur zona bening sekitar cakram kertas yang telah ditetesi sediaan uji. Semakin besar diameter zona hambat, maka semakin 
kuat potensi antibakteri dari sediaan uji tersebut. Dalam pengujian ini dibuktikan bahwa aktivitas penandaan tidak mengubah secara signifikan potensi antibakteri dari Kanamycin terhadap bakteri, baik bakteri Gram negatif maupun bakteri Gram positif, hal ini terlihat dari diameter zona hambat Kanamycin dan ${ }^{99 \mathrm{~m} T \mathrm{~T}-K a n a m y c i n}$ yang tidak berbeda secara signifikan terhadap bakteri, baik Gram negatif (E.coli) maupun Gram positif (S.aureus). Hasil pengujian daya hambat dapat dilihat pada Gambar 1.

Sebelum dilakukan uji in-vivo dengan membuat hewan model terinfeksi maka perlu dilakukan uji in-vitro sebagai acuan ketika melakukan uji in-vivo sehingga penggunan hewan percobaan lebih efektif. Uji in-vitro yang dilakukan bertujuan untuk mengetahui seberapa banyak sediaan 99mTc-Kanamycin berikatan dengan bakteri $E$. coli maupun S.aureus. Uji ini dikenal dengan uji uptake terhadap bakteri/uji pengikatan terhadap bakteri. Hasil yang diperoleh dapat dilihat pada Gambar 2 yang menunjukkan uptake yang semakin besar terhadap bakteri S. aureus dan paling besar terjadi pada 24 jam pasca inkubasi. Sedangkan pada bakteri E.coli, uptake menurun pada inkubasi 5 jam dan kembali naik pada inkubasi 24 jam. Pada aplikasinya, data yang diperoleh pada waktu inkubasi

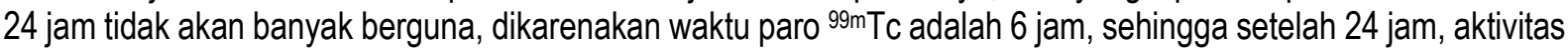
sediaan akan berkurang sebesar $1 / 16$ kali dari aktivitas awal, yang artinya sudah jauh berkurang dan diagnosis yang dilakukan menjadi tidak efektif. Gambar 3 menunjukkan perbandingan uptake ${ }^{99 \mathrm{mTc}} \mathrm{T}-\mathrm{Kanamycin} / \mathrm{Na}^{99 \mathrm{~m}} \mathrm{TcO}_{4}{ }^{-}$ terhadap bakteri E.coli dan S. aureus pada waktu inkubasi selama 1, 3, 5 dan 24 jam. Perbandingan uptake sediaan lebih besar pada bakteri S.aureus dibandingkan pada E.coli. Hasil ini sejalan dengan pengujian daya hambat yang menunjukkan aktivitas penghambatan yang lebih besar pada S.aureus dibandingkan pada E.coli. Hal tersebut disebabkan karena perbedaan susunan/komponen dinding sel pada bakteri S.aureus dengan E.coli. Sebagai bakteri gram positif S.aureus dinding selnya hanya terdiri dari peptidoglikan sedangkan bakteri Gram negatif (E.coli) dinding selnya terdiri dari peptidoglikan dan lipopolisakarida. Perbedaan tersebut menyebabkan S.aureus lebih rentan terhadap Kanamycin sehingga nilai daya hambat dan uptake terhadap S. aureus lebih besar daripada E.coli. Hasil ini juga sejalan dengan penelitian yang telah dilakukan oleh M. Jehangir, et.al, (6) yang telah membuktikan bahwa Kanamycin memiliki uptake in-vivo yang besar terhadap S.aureus.

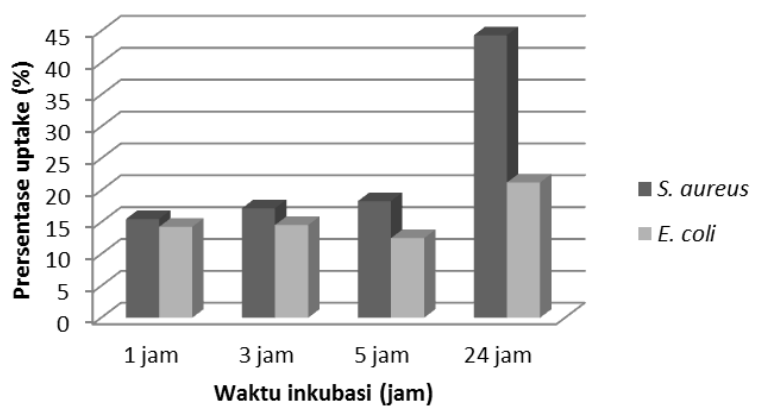

Gambar 2. Hasil uptake sediaan 99mTc-Kanamycin.

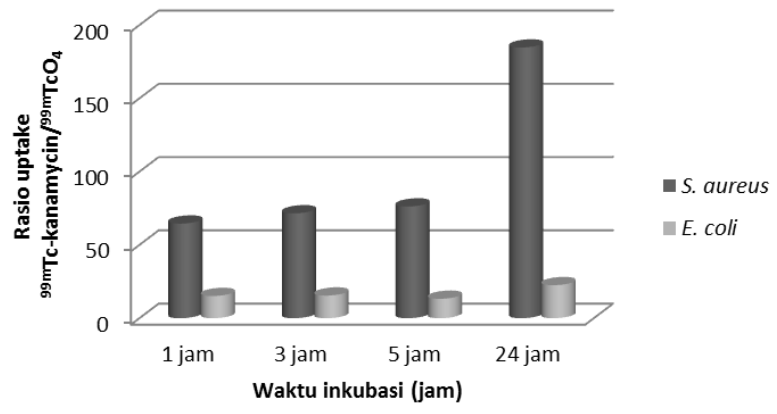

Gambar 3. Rasio uptake ${ }^{99 m T c-K a n a m y c i n / ~} / \mathrm{TCO}_{4}{ }^{-}$terhadap bakteri E.coli dan S.aureus. 

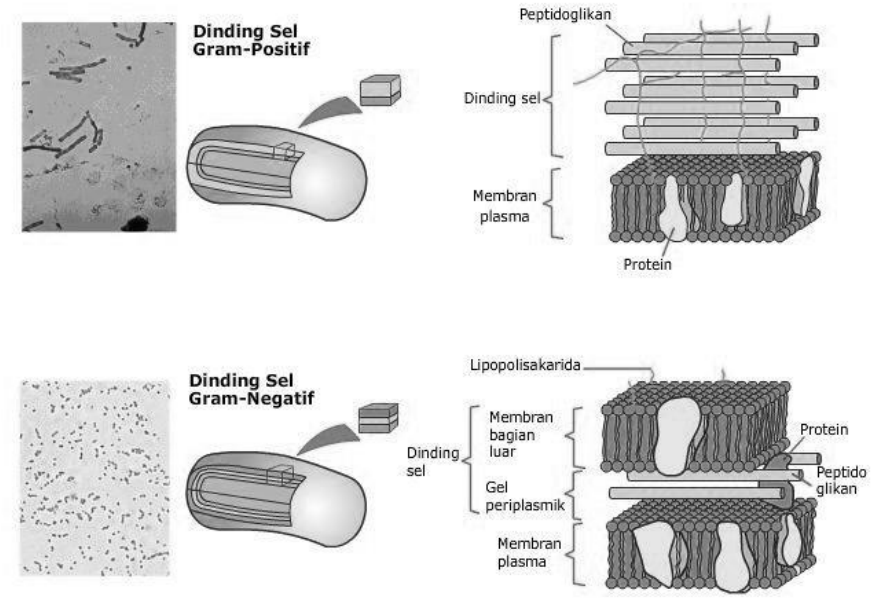

Gambar 4. Dinding sel bakteri Gram positif dan Gram negatif (18).

\section{KESIMPULAN}

Telah berhasil dibuat sediaan ${ }^{99 m T c-K a n a m y c i n ~ y a n g ~ s t e r i l, ~ b e b a s ~ p i r o g e n, ~ t i d a k ~ t o k s i k ~ d e n g a n ~ d a y a ~}$ hambat terhadap bakteri yang tidak berbeda secara signifikan dengan Kanamycin tidak bertanda radioaktif. Pengujian uptake sediaan ${ }^{99 m T c-K a n a m y c i n ~ t e r h a d a p ~ b a k t e r i ~ m e m b e r i k a n ~ h a s i l ~ y a n g ~ s e j a l a n ~ d e n g a n ~ h a s i l ~}$ pengujian daya hambat bakteri yaitu lebih besar pada S. aureus dibandingkan E.coli.

\section{DAFTAR PUSTAKA}

1. T.H. BASRY, N. ZAINUDDIN, dan R. ILJAS, "Formulasi Radiofarmaka ${ }^{99 m}$ Tc-Siprofloksasin Untuk Diagnosis Infeksi", Prosiding Seminar Nasional Sains dan Teknik Nuklir, Bandung (2005), 38 - 45

2. N. ZAINUDDIN, B. HIDAYAT, dan R. ILJAS, Pengembangan dan Aplikasi Klinis Kit -Kering Radiofarmaka Siprofloksasin. Jurnal Sains dan Teknologi Nuklir; X(1), (2009), 11 - 23

3. A. HANAFIAH W., dan N. KARTINI O., $99 \mathrm{~m} T c$-ethambutol Radiopharmaceutical for Diagnosis of Tuberculosis (Profile and its preliminary application), Majalah Kedokteran Bandung, XXXIX (2) (2007) 62 - 68

4. S. ROOHI , A. MUSHTAQ, M. JEHANGIR, DAN S.A. MALIK, Synthesis, Quality Control and Biodistribution of ${ }^{99 m}$ Tc-Kanamycin, Journal of Radioanalytical and Nuclear Chemistry, 267 (2006) 561 - 566

5. S. ROOHI, Preparation and Quality Control of Technetium-99m Labelled Compounds for Diagnostic Purpose, Tesis Program Doktor, Quaid-I-Azam University, (2006) 1 - 64

6. M. JEHANGI, A. MUSHTAQ, S.A. MALIK, DAN S. ROOHI, "Synthesis and Evaluation of 99mTc-Kanamycin and ${ }^{99 m}$ Tc-Isoniazid for Infection Imaging", Proceedings of International Symposium, Vienna, Austria, International Atomic Energy Agency (2007) 149 - 165

7. E.M. WIDYASARI, N. ZAINUDDIN, dan W. NURAENI, Penandaan Kanamycin dengan Radionuklida Teknesium-99m Sebagai Sediaan Untuk Deteksi Dini Penyakit Infeksi, Jurnal IImiah Aplikasi Isotop dan Radiasi, IX (2) (2013) 91 - 100

8. E.M. WIDYASARI, MISYETTI, T.H.A. WIBAWA, dan W. NURAENI, Karakteristik Fisikokimia Kit Kering Kanamycin, Jurnal Sains dan Teknologi Nulir XIV (2) (2013) 117 - 126

9. ANONYMOUS, Farmakope Indonesia Edisi IV, DEPARTEMEN KESEHATAN REPUBLIK INDONESIA, Jakarta, (1995), 855 - 919

10. ANONYMOUS, Technical Reports Series No. 466, Eds, Tecnetium-99m Radiopharmaceuticals: Manufacture of Kits, INTERNATIONAL ATOMIC ENERGY AGENCY- IAEA, Vienna-Austria (2008)

11. R.J. SUGIHARTI DAN N. KARTINI, "Uji Toksisitas Radiofarmaka 99mTc-Etambutol pada mencit (Mus musculus)", Prosiding Seminar Nasional Sains dan Teknologi Nuklir, Bandung (2007), 334 - 339 
12. D. MARZIN, Preclinical Evaluation Of Radiopharmaceutical Toxicological Prerequisites, Nuclear Medicine \& Biology, 25 (1998) $733-736$

13. G.B. SAHA, Fundamentals of Nuclear Pharmacy. $5^{\text {th }}$ ed., Springer Science, New York (2004)

14. DUCHEFA BIOCHEMIE B.V, MSDS Kanamycin Monosulfate. [Online] http://www.bioeng.nus.edu.sg/ cellular/msds/k0126.pdf. 18 Juli 2006, diakses tanggal 19 Mei 2014

15. ACCROS ORGANIC, MSDS Tin(II) chloride. [Online] http://www.ch.ntu.edu.tw/ genchem99/msds/ exp10/SnCl2.pdf. 22 Januari 2008, diakses tanggal 17 Januari 2014

16. SCIENCE LAB.COM, MSDS Sodium Pyrophosphate [Online] http://www.sciencelab.com/msds.php? msdsld=9925030. 21 Mei 2013, diakses tanggal 18 Juni 2014

17. The Free Dictionary, In-Vitro Susceptibility Testing. [Online] http://medical-dictionary.thefreedictionary.com/ in+vitro+susceptibility+testing, diakses tanggal 13 Januari 2013

18. Chemistry has solution: Bakteri dan antibiotic [Online] http://endiferrysblog.blogspot.com/2011/11/bakteridan-antibiotik.html., diakses tanggal 18 Juni 2014 